\title{
Resistance of spores of Aspergillus fumigatus to ingestion by phagocytic cells
}

\author{
MAURA D ROBERTSON, ANTHONY SEATON, L J R MILNE, J A RAEBURN \\ From the Institute of Occupational Medicine and the Western General Hospital, Edinburgh
}

ABSTRACT Phagocytic cells are believed to have an important role in the eradication of fungat spores from the lung. The ability of human and mouse cells to phagocytose the opportunistic fungusis Aspergillus fumigatus has been examined, spores of the non-pathogenic fungus Penicillium ochro $\overrightarrow{0}$ chloron being used for comparison. Most spores became associated with cells. Those of $A$ fumigatu\$ appeared to remain bound to the surface of the phagocyte rather than being ingested; in contrast ${ }_{2}^{-}$ $P$ ochrochloron spores appeared to be phagocytosed more readily, although they also were seen, in smaller numbers, on the cell surface. In view of the subjective nature of these observations, the effects of spore diffusates on phagocytosis were examined. Diffusates from spores of $A$ fumigatus were shown to inhibit phagocytosis of antibody coated radiolabelled sheep red blood cells byo primed mouse phagocytic cells. Diffusates of spores of $P$ ochrochloron had no such effect. These results suggest that when spores of $A$ fumigatus become bound to the surface of phagocytes they are able to release a substance that inhibits their ingestion while having little or no effect on surface binding.

Inhalation of spores of the opportunistic fungus Aspergillus fumigatus may lead to allergic disease in man $^{1}$ and in the immunosuppressed may cause life threatening infection. ${ }^{2}$ While phagocytic cells are clearly important in host defences against invading microorganisms, ${ }^{3-5}$ their precise role in the killing of A fumigatus remains undefined. ${ }^{6-11}$ Phagocytosis is often an important step in the killing of microorganisms, and this has generally been assumed to be the case with inhaled fungal spores. In one study, however, no evidence of phagosome-lysosome fusion was found in relation to phagocytosis of $A$ fumigatus, ${ }^{12}$ and recent studies from our laboratories have shown that this organism is able to produce a diffusate that significantly inhibits the respiratory burst of phagocytic cells. ${ }^{13}$ A fumigatus spores moreover, as we have suggested in a preliminary report, may be particularly resistant to phagocytosis. ${ }^{14}$

The process of phagocytosis can be divided into two phases: (1) attachment of the particle to the cell surface, followed by (2) ingestion. Steps 1 and 2 are collectively referred to as cell association. Only when a particle has undergone step 2 can it be said to be

Address for reprint requests: Mrs $M$ D Robertson, Institute of Occupational Medicine, 8 Roxburgh Place, Edinburgh EH8 9SU.

Accepted 8 December 1986 phagocytosed. Nevertheless, the term phagocytosis is often used synonymously with cell association implying that the particle is phagocytosed when the techniques used are unable to distinguish clearly between attached and ingested particles. In this paper we report further studies of the interactions between spores of A fumigatus and phagocytic cells, with par ticular reference to the two phases of the phagocytic process.

\section{Methods}

The study was designed to assess, by light and elec $\frac{7}{0}$ tron microscopy, the ability of phagocytic cells to ingest spores of $A$ fumigatus and, for comparison, $P_{S}$ ochrochloron. Since this assessment is necessarily sub+u jective, a well established method of assessing the number of ingested labelled sheep red blood cells accurately has been used to investigate the effects of diffusates of these spores on the phagocytic process.

\section{PHAGOCYTIC CELLS AND SERA}

Human monocytes and polymorphonuclear leuco $0 \overline{0}$ cytes were isolated from the peripheral blood of sixp healthy donors by density gradient centrifugation. ${ }^{1}$ 蛋 Autologous serum was obtained from a clotted blood sample at the same time. Serum containing specifie antibody to $A$ fumigatus was obtained from a patieng 
with an aspergilloma, and this produced about 10 precipitin lines when tested against a standard $A$ fumigatus antigen preparation (Bencard Allergy Division).

Peritoneal exudate cells were harvested from 12 week old syngeneic C57B1/6 mice by lavaging the peritoneal cavity with isotonic saline. The mice were pretreated by intraperitoneal injection of either $3 \%$ thioglycollate broth $(0.5 \mathrm{ml}$, Difco Products) four days before harvesting or Corynebacterium parvum, $0.2 \mathrm{ml}$ of $7 \mathrm{mg} / \mathrm{ml}$ (Wellcome Biotechnology Limited) five days before harvesting.

\section{FUNGAL SPORES AND DIFFUSATES}

The method used was that described previously, ${ }^{13}$ with the slight modification that after opsonisation spores of $\boldsymbol{A}$ fumigatus and $\boldsymbol{P}$ ochrochloron were used directly in the assays, suspended in RPM1-1640-5\% serum.

ESTIMATION OF CELL ASSOCIATION OF FUNGAL SPORES IN VITRO

Fifty microlitres of human phagocytic cells $(1 \times$ $10^{7} / \mathrm{ml}$ in RPM $1-5 \%$ autologous serum) were added to microtitre plates. At the same time control wells containing $50 \mu \mathrm{l}$ of RPM1-5\% serum alone were set up. To all wells $100 \mu \mathrm{l}$ of opsonised spores $(5 \times$ $10^{6} / \mathrm{ml}$ in RPM $1-5 \%$ serum) were added to give a final spore:phagocytic cell ratio of $2: 1$ or $1: 1$. To accelerate the contact process between spores and cells microtitre plates were centrifuged at $125 \mathrm{~g}$ for five minutes, then incubated at $37^{\circ} \mathrm{C}$ for one hour. After gentle mixing to resuspend sedimented spores, an aliquot of supernatant was removed and the number of free spores present was counted with an improved Neubauer counting chamber. Total spores were estimated from the number of spores in the supernatant of the control wells containing spores alone; this was used as a baseline to determine the percentage of spores becoming cell associated, the following formula being used:

$\%$ of spores cell associated $=\left(\frac{\text { total spores }- \text { spores non-cell associated }}{\text { total spores }}\right) \times 100$. All experiments were carried out in triplicate.

MICROSCOPY OF CELL-S PORE PREPARATIONS

Phagocytic cells $\left(200 \mu\right.$ l of $5 \times 10^{6} / \mathrm{ml}$ in RPM $1-5 \%$ autologous serum) were allowed to adhere to glass microchamber slides (LAB-TEK) or glass coverslips (13 mm diameter) for one hour at $37^{\circ} \mathrm{C}$ in $5 \%$ carbon dioxide. The coverslips were then gently rinsed twice in warm Hanks' balanced salt solution (HBSS) to remove non-adherent cells. Opsonised spores in RPM1-5\% autologous serum were added to the adherent phagocytic cells at a spore:cell ratio of $2: 1-1: 1$ and the cultures incubated at $37^{\circ} \mathrm{C}$ in $5 \%$ car- bon dioxide for 1.5 hours. After this period excess spores were removed by gently washing the cultures in warm HBSS three times. The slides were fixed in methanol and stained in May-Grünwald-Giemsa. ${ }^{16}$ The coverslips were processed for scanning electron microscopy ${ }^{17}$ by fixing at $37^{\circ} \mathrm{C}$ for 30 minutes in $2.5 \%$ glutaraldehyde (Sigma) in $0.1 \mathrm{~mol} / 1$ cacodylate buffer containing $0.1 \mathrm{~mol} / \mathrm{l}$ sucrose (Sigma) followed by two rinses in the buffer. The coverslips were then dehydrated in graded series of acetone-water mixtures and critically point dried with liquid carbon dioxide. This method was used because light microscopy does not differentiate between spores that have been phagocytosed and those that remain on the surface of phagocytes.

PHAGOCYTOSIS OF FUNGAL SPORES IN VIVO $\mathrm{C} 57 \mathrm{~B} 1 / 6$ mice that had received an intraperitoneal injection of $3 \%$ thioglycollate $(0.5 \mathrm{ml})$ four days previously were challenged intraperitoneally with $10^{8}$ spores in $0.5 \mathrm{ml} \mathrm{HBSS}$. After 1.5 hours the peritoneal cavities were lavaged with $5 \mathrm{ml}$ of HBSS; the lavaged cell population with attached or ingested spores was allowed to adhere to coverslips for one hour at $37^{\circ} \mathrm{C}$ and was then prepared for light and scanning electron microscopy.

\section{PHAGOCYTOSIS OF RADIOLABELLED ANTIBODY COATED SHEEP RED BLOOD CELLS}

The method was based on that described by Shaw and Griffin. ${ }^{18}$ Sheep red blood cells in Alsever's solution (Tissue Culture Service) were washed three times in phosphate buffered saline (PBS). The washed packed sheep red blood cells were radiolabelled by incubation in ${ }^{51} \mathrm{Cr} \mathrm{Na} \mathrm{CrO}_{4}\left(10^{8}\right.$ sheep red blood cells $/ 100 \mu \mathrm{Ci}$ ${ }^{51} \mathrm{Cr}$ ) (Amersham International) for one hour at $37^{\circ} \mathrm{C}$. The ${ }^{51} \mathrm{Cr}$ labelled sheep red blood cells were washed once in PBS and adjusted to $10^{9}{ }^{51} \mathrm{CR}$ labelled sheep red blood cells $/ \mathrm{ml}$. This suspension was then divided into two aliquots and the following were added: (1) an irrelevant antibody, mouse immunoglobulin (IgG) (Sigma) at $10 \mu \mathrm{g} / 10^{7}$ sheep red blood cells and (2) monoclonal antibody to sheep red blood cells (mouse IgG anti-sheep red blood cells (Sera Laboratories) at $10 \mu \mathrm{g} / 10^{7}$ sheep red blood cells). These mixtures were incubated for 15 minutes at $37^{\circ} \mathrm{C}$ then washed twice in ice cold PBS. The antibody coated ${ }^{51} \mathrm{Cr}$ sheep red blood cells were then suspended in RPM1-20\% heat inactivated fetal calf serum at a concentration of $4 \times 10^{7} / \mathrm{ml}$. C parvum stimulated mouse peritoneal exudate cells were added to flat-bottomed Removawells (Dynatech) at a concentration of $2 \times 10^{5} /$ well in $100 \mu$ l of RPM1-10\% heat inactivated fetal calf serum. The cells were left to adhere for three hours at $37^{\circ} \mathrm{C}$ in $5 \%$ carbon dioxide, and then washed twice in warm HBSS. The experi- 
ment consisted of five separate treatments. To the adherent mouse peritoneal exudate cells $50 \mu$ l of one of the following treatments was added: (1) HBSS plus $50 \mu \mathrm{l}$ of ${ }^{51} \mathrm{Cr}$ labelled sheep red blood cells that had been opsonised in mouse IgG; (2) HBSS alone; (3) $A$ fumigatus diffusate; (4) $P$ ochrochloron diffusate; (5) a known inhibitor of phagocytosis - cytochalasin B at $25 \mu \mathrm{g} / \mathrm{ml}$ (Sigma). To treatments $2-550 \mu \mathrm{l}$ of ${ }^{51} \mathrm{Cr}$ labelled sheep red blood cells opsonised in mouse IgG anti-sheep red blood cells was added. The Removawells were centrifuged for five minutes at 125 $g$, then incubated at $37^{\circ} \mathrm{C}$ in $5 \%$ carbon dioxide for 1.5 hours. The supernatant was removed and $100 \mu \mathrm{l}$ of ice cold red cell lytic buffer (to lyse nonphagocytosed sheep red blood cells) was added. After five minutes the lytic buffer was removed and the cells were washed three times in cold PBS. The Removawells containing cells with phagocytosed ${ }^{51} \mathrm{Cr}$ labelled sheep red blood cells were counted in a gamma counter (LKB-Rack Gamma II). For each experiment five replicates were performed.

\section{STATISTICAL ANALYSES}

The results of the cell association of the fungal spores were analysed by a three way analysis of variance, the data having been transformed on a logistic scale:

$$
\log \left(\frac{\% \text { cell associated }}{100-\% \text { cell associated }}\right) \text {. }
$$

For the sheep red blood cells phagocytosis experiments a two way analysis of variance was used on the $\log$ transformed data. Student's $t$ tests were used to assess the statistical significance of treatment contrasts, estimates of residual error being obtained from the analyses of variance.

\section{Results}

\section{ASSOCIATION OF FUNGAL SPORES AND HUMAN} PHAGOCYTIC CELLS

Most (> 77\%) of the opsonised spores of both $A$ fumigatus and $P$ ochrochloron became cell associated with both monocytes and polymorphonuclear cells after incubation in vitro for one hour at $37^{\circ} \mathrm{C}$ (table 1). No significant differences were found between

Table 1 Percentage of opsonised spores that became cell associated after one hour in vitro (means (SEM) of results from the six donors)

\begin{tabular}{|c|c|c|}
\hline Fungal spores & Cell type & $\begin{array}{l}\% \text { of cell } \\
\text { associated spores }\end{array}$ \\
\hline $\begin{array}{l}\text { Aspergillus fumigatus } \\
\text { A fumigatus } \\
\text { Penicillium ochrochloron } \\
P \text { ochrochloron }\end{array}$ & $\begin{array}{l}\text { Monocyte } \\
\text { Polymorphonuclear } \\
\text { Monocyte } \\
\text { Polymorphonuclear }\end{array}$ & $\begin{array}{l}87 \cdot 8(3 \cdot 2) \\
80 \cdot 4(9 \cdot 5) \\
80 \cdot 7(4 \cdot 7) \\
77 \cdot 5(6 \cdot 4)\end{array}$ \\
\hline
\end{tabular}

spore or cell type. Examination by light microsco of slide preparations of the cell-spore interactions alse confirmed that a substantial number of spores hat become cell associated. It was not possible, howeve्? to distinguish between attached and ingested cells means of light microscopy.

SCANNING ELECTRON MICROSCOPY OF FUNGAF SPORES AND HUMAN PHAGOCYTIC CELLS Scanning electron microscopy shows fungal spores $\overrightarrow{a s}$ small rounded bodies closely associated with the phagocytic cell membrane. The degree to which the spore has become cell associated has been arbitrarif divided into three phases: (1) attached-spore lyiig

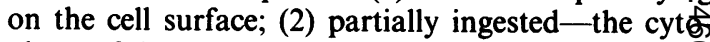
plasm of the cell enclosing the spore yet not fully cof ering it; and (3) ingested-the outline of the spore being seen under the cytoplasm of the cell.
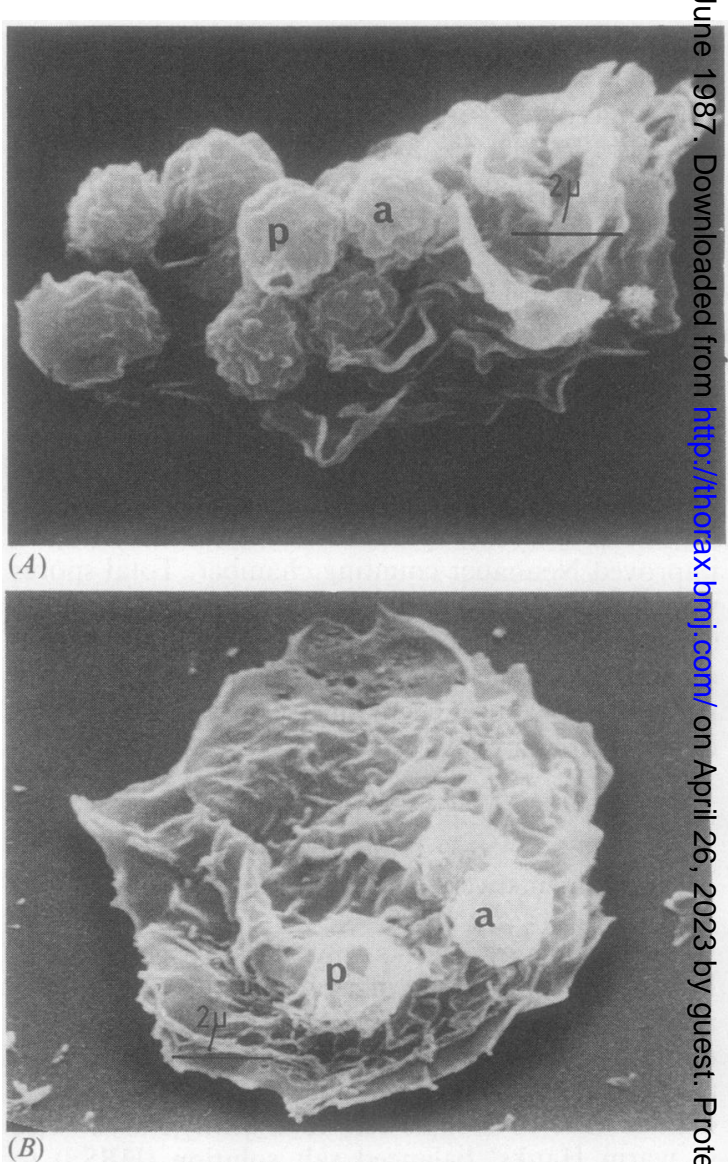

Fig 1 Scanning electron micrographs of the interaction after 1.5 hours in vitro between spores of Aspergillus fumigatus and $(A)$ a human monocyte and $(B)$ a human polymorphonuclear cell. a-attached spore; p-partially ingested spore. 
With scanning electron microscopy a substantial number of spores of $A$ fumigatus were found to be attached to the surface of the phagocytic cell and not internalised after incubation at $37^{\circ} \mathrm{C}$ for 1.5 hours (fig 1). Although spores of $P$ ochrochloron were present on the surface of the cell they appeared to be less numerous. Opsonisation of the fungal spores in sera containing specific antibody to $A$ fumigatus did not appear to alter this finding.

\section{CELL ASSOCIATION OF SPORES .WITH MOUSE PHAGOCYTIC CELLS}

A mouse model was used to examine whether the finding obtained by in vitro experimentation could be repeated in vivo. We initially examined the interaction in vitro of opsonised fungal spores with thioglycollate elicited mouse peritoneal exudate cells and found that this gave results similar to those obtained with human phagocytes (fig 2). In vivo experiments, in which spores were injected into the peritoneal cavity of the mouse followed with lavage 1.5 hours later, once again gave a similar result. A substantial number of $A$ fumigatus spores were seen to be bound to the surface of the cells in vivo, while spores of $P$ ochrochloron were in general becoming ingested (fig 3).

\section{PHAGOCYTOSIS OF ANTIBODY COATED ${ }^{51} \mathrm{Cr}$ LABELLED SHEEP RED BLOOD CELLS BY MOUSE PHAGOCYTES}

We measured the effect of spore diffusates of $A$ fumigatus and $P$ ochrochloron on the phagocytosis by $C$ parvum stimulated mouse peritoneal exudate cells of antibody coated ${ }^{51} \mathrm{Cr}$ labelled sheep red blood cells. This technique has the advantage that all extracellular (non-ingested) sheep red blood cells, including those attached to the cell surface, may be removed by lysis with red blood cell lytic buffer, thereby enabling an accurate measurement of phagocytosis to be made. There was significantly more phagocytosis ( $p<$ 0.0005) of the specific anti-sheep red blood cells coated cells than of those coated with irrelevant mouse IgG (table 2). This result established the validity of the technique. The ${ }^{51} \mathrm{Cr}$ labelled sheep red blood cells coated in specific anti-sheep red blood cells antibody were used to assess the effects of the spore diffusate. Diffusates of $A$ fumigatus inhibited phagocytosis by about $63 \%(\mathrm{p}<0.0025)$ while spore diffusates of $P$ ochrochloron had no significant effect (table 2). As a positive control we included in the assay $1.25 \mu \mathrm{g}$ of cytochalasin B, a known inhibitor of phagocytosis; this inhibited the phagocytosis of specific anti-sheep red blood cells coated labelled sheep red blood cells by $44 \%(p<0.005)$.

\section{Discussion}

An intriguing aspect of the biological behaviour of $A$

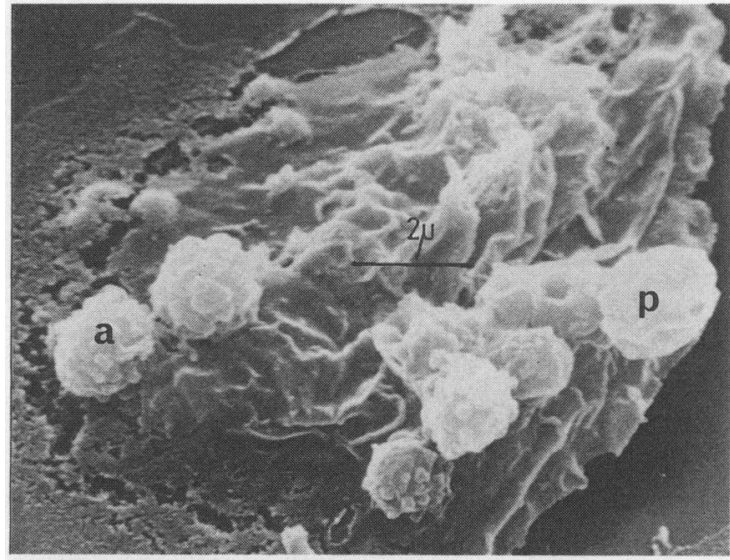

(A)

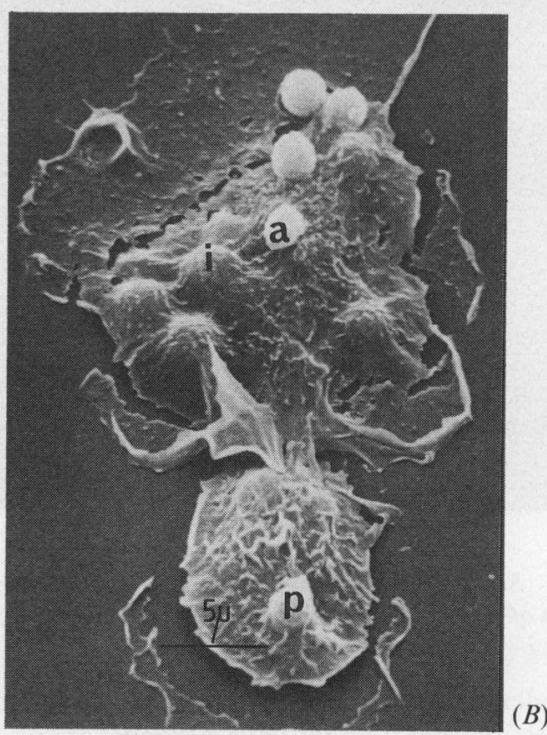

Fig 2 Scanning electron micrographs of the interaction in vitro for 1.5 hours of mouse peritoneal exudate cells and $(A)$ spores of Asperigillus fumigatus and $(B)$ spores of Penicillium ochrochloron. a-attached spore; $p$-partially ingested spore; $i$-fully ingested spore.

fumigatus is its ability to colonise the human bronchopulmonary system under certain circumstances. This has allowed it to become an important pathogen in immunosuppressed patients, ${ }^{2}$ a cause of severe postinfluenzal lung infection, ${ }^{19}$ and a coloniser of lung cavities, ${ }^{20}$ as well as provoking asthma and allergic bronchopulmonary aspergillosis in some people. This association with such a range of diseases makes it unique among fungi pathogenic to man.

Some years ago it was found that $A$ fumigatus could be isolated from postmortem human lung more frequently than would have been anticipated from the 

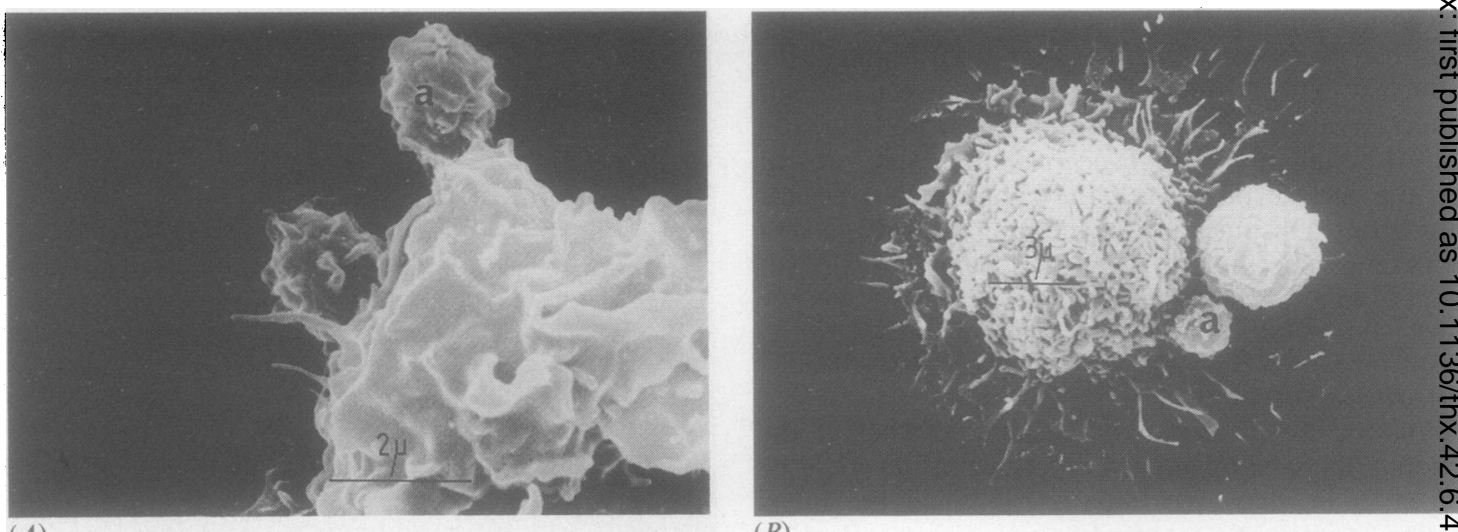

$(A)$

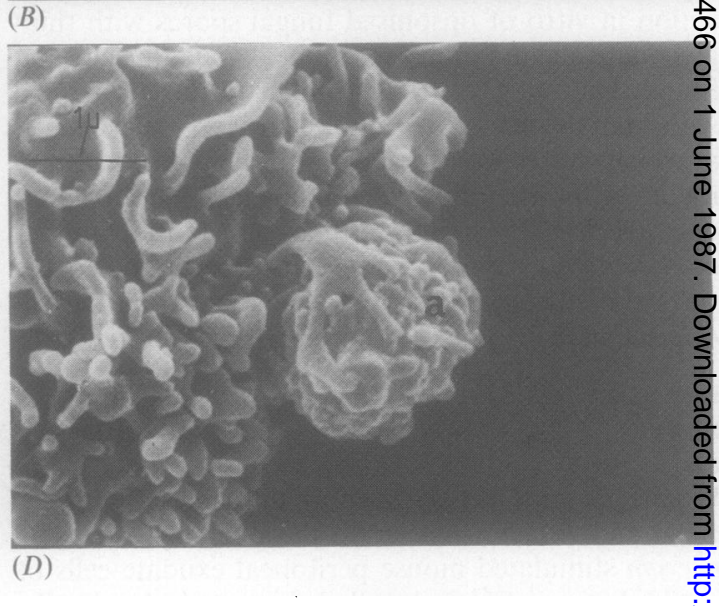
$(C)$

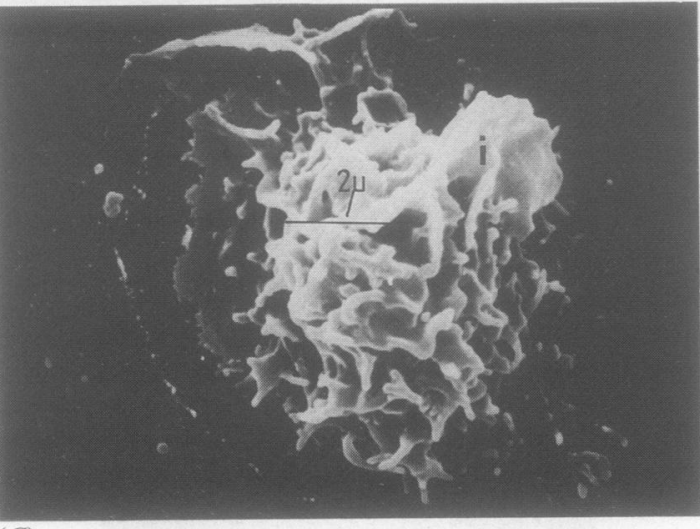

Fig 3 Scanning electron micrographs of the interaction in vivo for 1.5 hours of mouse peritoneal exudate cells and ( $A$ and $B$ spores of Aspergillus fumigatus and ( $C$ and $D)$ spores of Penicillium ochrochloron. a-attached spore; $p$-partially ingested 0 spore; $i-$ fully ingested spore.

prevalence of its spores in the air. ${ }^{21}$ This led to the suggestion that it might have a specific ability to resist the natural defences of the lung; its small spore size and optimal temperature for germination $\left(37^{\circ} \mathrm{C}\right)$ were other factors considered likely to be important. This led us to study the interactions of spores with phago-

Table 2 Effect of spore diffusates on the phagocytosis of antibody coated radiolabelled sheep red blood cells $\left({ }^{51} \mathrm{Cr}\right.$ srbc) by mouse phagocytes (means (SEM) of results of three separate experiments)

\begin{tabular}{|c|c|c|}
\hline Treatment & $\begin{array}{l}\text { Antibody coating } \\
\text { of }{ }^{51} \text { Cr srbc }\end{array}$ & $\begin{array}{l}\text { Phagocytosis } \\
\text { (CPM) }\end{array}$ \\
\hline $\begin{array}{l}\text { HBSS } \\
\text { HBSS }\end{array}$ & $\begin{array}{l}\text { Mouse IgG } \\
\text { Anti-srbc }\end{array}$ & $\begin{array}{r}87.1(10.04) \\
440 \cdot 5(36 \cdot 6)\end{array}$ \\
\hline Aspergillus fumigatus & Anti-srbc & $161.8(29.4)$ \\
\hline $\begin{array}{l}\text { Penicillium ochrochloron } \\
\text { diffusate } \\
\text { Cytochalasin B }\end{array}$ & $\begin{array}{l}\text { Anti-srbc } \\
\text { Anti-srbc }\end{array}$ & $\begin{array}{l}408 \cdot 3(51 \cdot 6) \\
247 \cdot 8(34 \cdot 2)\end{array}$ \\
\hline
\end{tabular}

HBSS-Hanks' balanced salt solution. cytic cells in vitro. In a recent publication ${ }^{13} \underset{\leftarrow}{\stackrel{\circ}{\mathrm{ge}}}$ showed that spores of $A$ fumigatus produce a diffusate containing a low molecular weight factor that inhibits the respiratory burst of neutrophils and macrophages. This factor is given off by the spores aftert only brief incubation, in contrast to another inhibitory substance, named gliotoxin, shown others to inhibit phagocytosis by mouse peritonea exudate cells. ${ }^{22}$ Since gliotoxin is produced only after three days' incubation of $A$ fumigatus, by which time mycelial growth would be profuse, it is probably mycelial rather than a spore derived product.

Our finding that $A$ fumigatus spore producefs inhibited the respiratory burst of phagocytic cells lod us to consider another important leucocyte function the process of phagocytosis. In this paper we hage shown that the spores of $A$ fumigatus are relativety resistant to phagocytosis by human and mouse phagocytes. Initial studies, using light microscop, did not allow differentiation of ingested and surfase bound spores. Scanning electron microscopy ofd 
show that a high proportion of spores of $A$ fumigatus (and a lower proportion of spores of $P$ ochrochloron) were not taken into the cell but remained bound to the surface. This remained true when cells first encounterd spores in vivo in mice. Attempts were made to quantify this, by means of enzyme stripping techniques; but it proved very difficult to remove spores from cell surfaces. Further efforts, using transmission electron microscopy, also failed as it proved impossible to differentiate between ingested spores and those sectioned between folds of the phagocyte surface membrane. In view of these difficulties in quantifying the effect, we used a reliable assay of phagocytosis, the ingestion of radiolabelled sheep red blood cells coated with antibody. This allowed lysis of any surface associated red blood cells and assay of the numbers actually ingested. Diffusates of $A$ fumigatus, unlike those of $\boldsymbol{P}$ ochrochloron, significantly inhibited phagocytosis, thus confirming our microscopical observations. This may be the explanation of the findings of Lehrer and Jan, ${ }^{23}$ who showed that apparently "phagocytosed" spores (as judged by light microscopy) were nevertheless resistant to killing.

There is thus convincing evidence that $A$ fumigatus spores produce one or more substances that readily diffuse from the spore surface and have an inhibitory effect on phagocytosis. Similar mechanisms by which potential pathogens may evade phagocytosis have been shown to be important to the pathogenicity of other microorganisms. ${ }^{2425}$ It has been suggested that evasion of phagocytosis may be a principal method by which microorganisms escape macrophage defence function. ${ }^{26}$ The capacity of $\boldsymbol{A}$ fumigatus to resist phagocytosis may be an important factor contributing to its pathogenicity, and further studies are now taking place to characterise the diffusate and to examine other aspects of its effects on phagocytic cell function.

The authors would like to thank Mrs K Niven for operating the scanning electron microscope, Mrs D Lyster for printing the photographs, and Mr W Maclaren for the statistical analyses. This work is supported by the Asthma Research Council.

\section{References}

1 McCarthy DS, Pepys J. Allergic bronchopulmonary aspergillosis. Clinical immunology: (i) clinial features. Clin Allergy 1971;1:261-86.

2 Warren RE, Warnock DW. Clinical manifestations and management of aspergillosis in the compromised patient. In: Warnock DW, Richardson MD, eds. Fungal infection in the compromised hostl. Chichester: John Wiley and Sons, 1982:119-53.

3 Borregaard N. Bactericidal mechanisms of the human ' neutrophil. Scand J Haem 1984;32:225-30.

4 Klebanoff SJ, Hamon CB. Antimicrobial systems of mononuclear phagocytes. In: van Furth R, ed. Mononuclear phagocytes in immunity and infection and pathology. Oxford: Blackwell Scientific Publications, 1975:507-31.

5 Schuit KE. Phagocytosis and intracellular killing of pathogenic yeast by human monocytes and neutrophils. Infect Immun 1979;24:932-8.

6 Diamond RD, Huber E, Haudenschild CC. Mechanisms of destruction of Aspergillus fumigatus hyphae mediated by human monocytes. J Infect Dis 1983; 147:474-83.

7 Lehrer RI, Jan RG. Interaction of Aspergillus fumigatus spores with human leukocytes and serum. Infect Immun 1970;1:345-50.

8 White LO. Germination of Aspergillus fumigatus conidia in the lungs of normal and cortisone-treated mice. Sabouraudia 1977;15:37-41.

9 Waldorf AR, Levitz SM, Diamond RD. In vivo bronchoalveolar macrophage defence against Rhizopus oryzae and Aspergillus fumigatus. $J$ Infect Dis 1984;150:752-60.

10 Schaffner A, Douglas H, Braude A. Selective protection against conidia by mononuclear and against mycelia by polymorphonuclear phagocytes in resistance to Aspergillus. J Clin Invest 1982;69:617-31.

11 Levitz SM, Diamond RD. Mechanisms of resistance of Aspergillus fumigatus conidia to killing by neutrophils in vitro. $J$ Infect Dis 1985;152:33-42.

12 Kurup VP. In vitro infection of rabbit alveolar macrophages with Aspergillus spores. Abstracts of the Annual Meeting of the American Society of Microbiology 1981;81:317.

13 Robertson MD, Seaton A, Milne LJR, Raeburn JA. Suppression of host defences by Aspergillus fumigatus. Thorax 1987;42:19-25.

14 Robertson MD, Raeburn JA, Gormley'IPG, Seaton A. Do phagocytic cells ingest spores of Aspergillus fumigatus? [abstract]. Thorax 1985;40:237.

15 Ferrante A, Thong YH. Separation of mononuclear and polymorphonuclear leucocytes from human blood by the one-step hypaque-ficoll method is dependent on blood column height. J Immunol Methods 1982; 48:81-5.

16 Dacie JV, Lewis SM. Practical haematology. Edinburgh: Churchill Livingstone, 1975:70-2.

17 Walker SR, Shellburne JD. Preparative techniques for scanning electron microscopy. In: Adams DO, Edelson PJ, Koren J, eds. Methods for studying mononuclear phagocytes. London: Academic Press, 1981: 403-12.

18 Shaw DR, Griffin FM. Antibody-dependent and antibody-independent phagocytosis. In: Adams DO, Edelson PJ, Koren H, eds. Methods for studying mononuclear phagocytes. London: Academic Press, 1981: 511-27.

19 McLeod DT, Milne LJR, Seaton A. Successful treatment of invasive pulmonary aspergillosis complicating influenza A. Br Med J 1982;285:1166-7.

20 Buchanan DR, Lamb D. Saprophytic invasion of infarcted pulmonary tissue by Aspergillus species. Thorax 1982;37:693-8.

21 Mullins J, Seaton A. Fungal spores in lung and sputum. 
Clin Allergy 1978;8:525-33.

22 Müllbacher A, Waring P, Eichnar RD. Identification of an agent in cultures of Aspergillus fumigatus displaying anti-phagocytic and immunomodulating activity in vitro. J Gen Microbiol 1985;131:1251-8.

23 Lehrer RL, Jan RG. Interaction of Aspergillus fumigatus spores with human leukocytes and serum. Infect Immunol 1970;1:345-50.
24 Schwarzmann S, Boring JR III. Antiphagocytic effect of slime from a mucoid strain of Pseudomona aeruginosa. Infect Immunol 1971;3:762-7.

25 Smith H. Microbial surfaces in relation to pathogenicity Bacteriol Rev 1977;41:475-500.

26 Skamene E, Gros P. Role of macrophages in resistanc against infectious diseases. Clinic Immunol Allerg $\oplus$ 1983;3:539-60. 